\title{
NETWORK DEVELOPMENT OF THE WORLD'S HIGH-SPEED RAILWAYS
}

\author{
Sergey Anatolyevich Tarkhov \\ Institute of Geography, Russian Academy of Sciences \\ Staromonetnyi pereulok 29, 119017, Moscow: Russia \\ tram.tarkhov@gmail.com
}

\begin{abstract}
The first high-speed railway appeared in 1964 in Japan, which was the leader in this business up to its economic crisis in the 1990s. Certain European countries developed these railways in 198090s, and some other Asian states also joined this club. China commenced with the construction of its high-speed railways in the 2000s, transforming itself into the world's new leader in the field. This article is dedicated to a geographical analysis of the network development of high-speed railways in the years 1964-2017. Graph theory methods (network analysis) are applied to compare processes of development.
\end{abstract}

Key words: railways, high-speed railways, topological structure, network analysis.

\section{Introduction}

In recent times, all passenger railways have recently been classified - in terms of velocity - into the three groups of: 1) typical railways - velocity less than $140 \mathrm{~km} / \mathrm{h} ; 2$ ) fast railways - 140-200 km/h; 3) high-speed railways - $200 \mathrm{~km} / \mathrm{h}$ and more. Here, considerations are confined to high-speed railways (HSR), and their spread around the world in the period of 53 years since the category first made its appearance in Japan in 1964.

Major advantages in comparison with typical or fast railways are: 1) major reductions in journey times; 2 ) increases in train velocities up to $350-380 \mathrm{~km}$ per hour. Given such speeds, the construction of high-speed railway networks has obviously transformed the social and economic space of those countries in which it has taken place. High-speed railways have likewise changed the structure of urban systems drastically, given the consequent stimulation of the growth and attractiveness of those cities connected by the type of railways under consideration. Construction thus led to spatial transformations of both settlement and economic landscapes.

The overall global length of HSR lines changed very rapidly over the 2000-2017 period (from 5 thous. km in 2000 to over 42 thous. $\mathrm{km}$ in 2007) due construction work on a massive scale in China (Fig. $1^{1}$ ). Nevertheless, a total of 12 states have HSR networks, while 6 more have them under construction at the present time.

\footnotetext{
${ }^{1}$ The maps were designed by the author and prepared by Ekaterina Chebanova.
} 


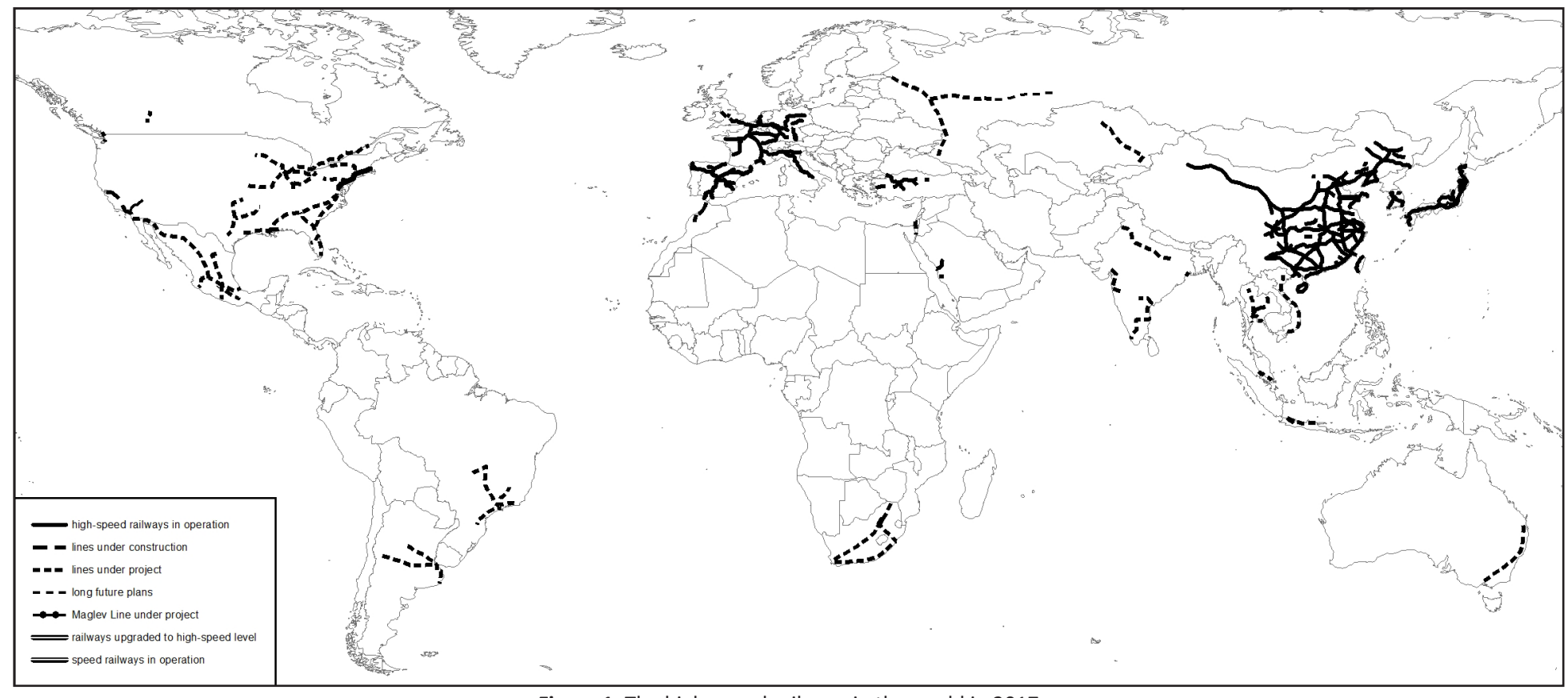


Europe and Asia are the main rivals in the HSR business (Table 1). While in the year 2000, there were 5 European states (France, Germany, Spain, Italy and Belgium) accounting for $53 \%$ of world HSR, with Asia (Japan only) on 47\%, by 2009 Asia's share was 54\%, and by the end of $201780 \%$. That of course entailed the share of the total accounted for by Europe decreasing to $46 \%$ in 2009 and $20 \%$ by the end of 2017 .

Table 1. National high-speed railway systems in the world in the $2000-2017$ period (at end of given year)*

\begin{tabular}{|c|c|c|c|c|c|c|c|c|}
\hline \multirow[t]{2}{*}{$\begin{array}{l}\text { Country / } \\
\text { Continent }\end{array}$} & \multirow[t]{2}{*}{$\begin{array}{l}\text { Opening } \\
\text { year of } 1^{\text {st }} \\
\text { HSR }\end{array}$} & \multicolumn{4}{|c|}{ HSR length [km] } & \multicolumn{2}{|c|}{$\begin{array}{l}\text { Share of country's } \\
\text { HSR length in global } \\
\text { HSR network [\%] }\end{array}$} & \multirow{2}{*}{$\begin{array}{c}\text { Passengers } \\
\text { transported } \\
\text { by HSR (million } \\
\text { per year) }\end{array}$} \\
\hline & & 2000 & 2009 & 2016 & 2017 & 2000 & 2016 & \\
\hline Japan & 1964 & 2416 & 2638 & 3059 & 3059 & 46.81 & 8.03 & 355 (2013) \\
\hline Italy & 1977 & 254 & 923 & 1059 & 1059 & 4.92 & 2.78 & $25(2011)$ \\
\hline France & 1981 & 1242 & 1872 & 2013 & 2497 & 24.07 & 5.28 & $130(2013)$ \\
\hline Germany & 1988 & 693 & 1032 & 1257 & 1447 & 13.43 & 3.30 & 76.6 (2012) \\
\hline Spain & 1992 & 472 & 1,963 & 3036 & 3036 & 9.15 & 7.97 & $\ldots$ \\
\hline Belgium & 1997 & 84 & 209 & 326 & 326 & 1.63 & 0.85 & $\ldots$ \\
\hline United Kingdom & 2003 & - & 113 & 113 & 113 & - & 0.30 & $\ldots$ \\
\hline China & 2003 & - & 4320 & 25398 & 28714 & - & 66.65 & $1,440(2016)$ \\
\hline South Korea & 2004 & - & 330 & 696 & 696 & - & 1.83 & 37.4 (2009) \\
\hline Taiwan & 2007 & - & 345 & 345 & 345 & - & 0.90 & 44.5 (2012) \\
\hline Netherlands & 2009 & - & 120 & 125 & 125 & - & 0.33 & $\ldots$ \\
\hline Turkey & 2009 & - & 235 & 677 & 677 & - & 1.78 & 2.26 (2013) \\
\hline WORLD & 1964 & 5161 & 14100 & 38104 & 42094 & 100.00 & 100,00 & $\ldots$ \\
\hline Asia & 1964 & 2416 & 7868 & 30175 & 33491 & 46.81 & 79.19 & $\ldots$ \\
\hline Europe & 1977 & 2745 & 6232 & 7929 & 8603 & 53.19 & 20.81 & $\ldots$ \\
\hline
\end{tabular}

* Countries are ordered by dates of opening of the first HSR. Bold characters indicate the three biggest HSR systems in each year.

... - no data available

Source: author's own compilation.

\section{Literature review}

In essence, there are no general geographical publications dealing with the spread of high-speed railways in the world, or in particular countries other China (Tarkhov 2016). Most articles in transport-related magazines are dedicated to economic and technical details of new high-speed railways under construction or inaugurated. There are many small articles about individual railway lines, their construction, and plans for expansion with maps. Such publications cover Brazil (New studies... 2015), China (Wang et al. 2014; High-speed rail services... 2015; Zhong et al. 2015), France (France and Italy... 2015), Germany (Munchen - Berlin... 2015), India (China carries out... 2015; India awards... 2015; Thakur 2015), Israel (Tunneling work... 2014), Italy (France and Italy... 2015), Japan (Construction begins on ... 2015; Hokuriku Shinkansen... 2015; Japanese maglev... 2015), Mexico (Mexican high-speed... 2014; Mexico restarts high-speed ... 2015), Morocco (France and Morocco... 2015; Moroccan high-speed line... 2015), Russia (770 km Moscow - Kazan ... 2015), South Korea (Korean president ... 2015), Spain (Spain extends... 2015; Spain launches... 2015) and the USA (142 km first ... 2015). 
The need for study of the impact of the new high-speed railways on the settlement and economic structure of areas adjacent to them does gain peripheral mention in the articles referred to (Wang et al. 2014; Zhong et al. 2015). But deep scientific analysis of the formation of high-speed rail frameworks, and their influence on the spatial systems of cities and economic nodes has remained absent. Apparently, time is needed for it to become clearly exactly how major the impact in question is, its type, and how exactly the influence on the systems in question is mediated.

Geographers may not avoid this new phenomenon fast diffusing across technologicallyadvanced countries. Yet they have not done enough to study the spatial component of the process (see remarks in: Tarkhov 2005, 2016); do not quite understand the spatial distinctions in the expansion of high-speed rail networks in individual countries; and do not fully understand the details of the influences exerted on local, regional and national settlement systems, as well as the concentration and dispersal of economic elements of a territory, and territorial structure as a whole.

\section{Methodology}

The work underpinning this article thus covers a major gap in the geographical coverage of the phenomenon in question. It is dedicated to description of the spatial growth of high-speed railways worldwide in a 53-year period following the technology's first appearance (1964-2017).

Comparative statistical and topological methods gain application in this study, with a quantitative comparison of the sizes of individual HSR networks over the years 1964-2017, as well as a comparison in relation to topological structure (using graph theory methods) as changes over the period in question took place. The work allowed for the identification of the following waves to the diffusion of HSR:

1) high-speed railways built in Japan (1964), Italy (1977) and France (1981);

2) Germany (1989), Spain (1992) and Belgium (1997), as countries of the second generation of HSR;

3) the UK (2003), China (2003), South Korea (2004), Taiwan (2007), Turkey (2009), and the Netherlands (2009).

\section{The development of high-speed railway networks}

\section{Countries with high-speed railways in operation}

Since 2009, China has the largest network in the world. Its first HSR (404 km) was opened in 2003. This network increased rapidly in size during the last decade (Table 2), with its share of the world total growing from 32\% in 2009 to $68 \%$ in 2017. The length will reach 34000 km (Figs. 2 and 3) by the end of 2019 (and constitute 75\% of the world network).

China has the HSR network of the most complex spatial structure to be found anywhere in the world, given the presence of more than 20 circuits. Its circuitous framework in fact extends across all the densely-populated areas of Eastern and Central China. 


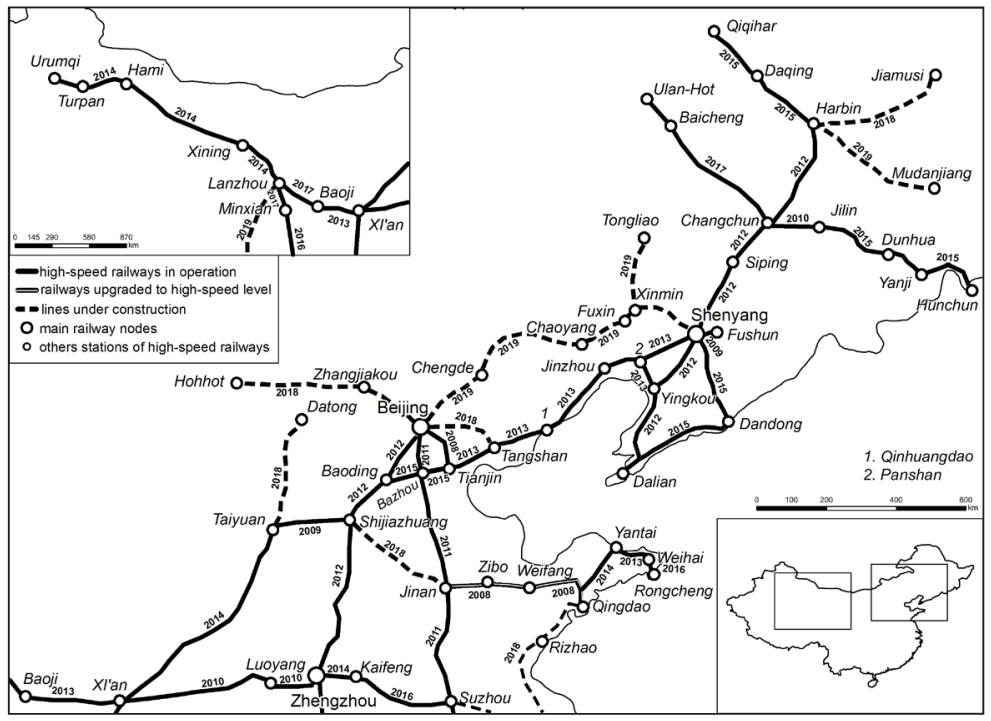

Figure 2. The high-speed railway network in northern China in 2017

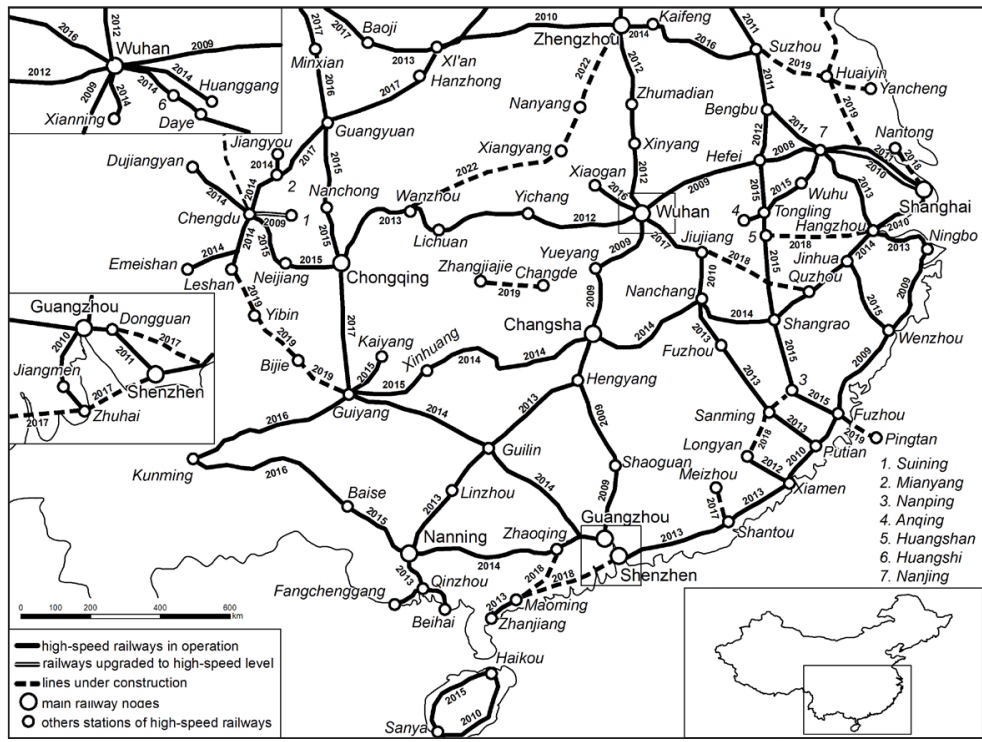

Figure 3. The high-speed railway network in southern China in 2017 
Table 2. Growth of the HSR network and numbers of passengers transported by HSR trains in China, 2007-2017.

\begin{tabular}{|c|c|c|c|}
\hline Year & HSR length, km (to end of year) & $\begin{array}{c}\text { Passengers carried by CRH } \\
\text { trains along all railways [M] }\end{array}$ & $\begin{array}{c}\text { Passengers carried by CRH trains } \\
\text { along HSR lines [M] }\end{array}$ \\
\hline 2007 & 404 & 86.50 & 61.21 \\
\hline 2008 & 1041 & 127.73 & 127.40 \\
\hline 2009 & 3443 & $\ldots$ & 179.58 \\
\hline 2010 & 5718 & $\ldots$ & 290.54 \\
\hline 2011 & 7140 & $\ldots$ & 440.00 \\
\hline 2012 & 9874 & $\ldots$ & 485.50 \\
\hline 2013 & 13277 & 672.00 & 530.00 \\
\hline 2014 & 19275 & 893.20 & $\ldots$ \\
\hline 2015 & 23458 & $1,100.00$ & 910.00 \\
\hline 2016 & 25398 & $\ldots$ & $1,440.00$ \\
\hline 2017 & 28714 & $\ldots$ & $\ldots$ \\
\hline
\end{tabular}

CRH - China Railway High-Speed; ... - no data available

Source: author's own compilation

Japan and Spain have HSR networks of almost the same size. The first Tokaido HSR line in Japan was opened in 1964 (as the first in the world). The network then expanded very rapidly during the 1970 and 80s, with some additions in the 1990s and in 2000-10s (Fig. 4). The network covers almost all the largest cities and stretches out from the north (the southern point of Hokkaido island) to the southern point of Kyushu, having several branches. Its topological structure is very simple in comparison with the Chinese HSR network, assuming a dendritic form.

Spain commenced with the construction of its HSR network quite late: the first (Madrid - Sevilla) line opened in 1992, but the network only expanded more rapidly in the 2000s, attaining
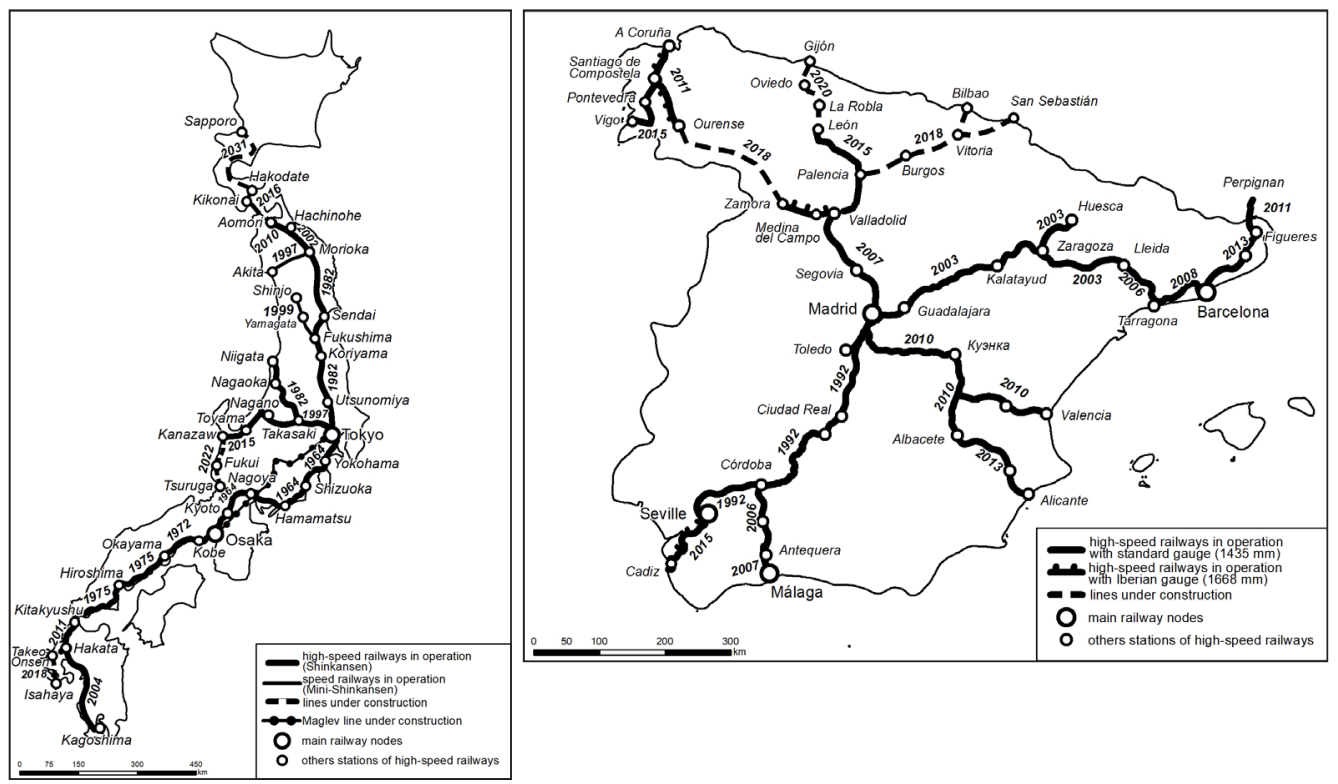

Figure 4. The high-speed railway network in Japan (left) and Spain (right) in 2017 
a length of over $3000 \mathrm{~km}$ by 2017. The Spanish HSR network is now Europe's largest and extends to almost all the country's major cities. It again has a dendritic structure (Fig. 4), but more complicated than the Japanese one. Most of the lines start from Madrid. There is also an isolated section in the north-west.

France takes $4^{\text {th }}$ place in the world ( $2^{\text {nd }}$ in Europe) when it comes to the size of its HSR network. The first line here was opened in 1981. The network grew to approximately $2500 \mathrm{~km}$ by 2017 (Fig. 5), due to the opening of two lines that year (302 km Tours-Bordeaux and $182 \mathrm{~km}$ Le MansRennes). It is dendritic like that of Spain, but almost all lines start from Paris. There are two isolated sections in the east and south.

It was in 1989 that Germany opened its first line (Fig. 5), connecting north and south. Due to the polycentric spatial structure of the country the HSR network presents itself as a system of 6 isolated fragments (Berlin-Hannover-Wurzburg, Koln-Frankfurt-am-Main, Leipzig-Erfurt, Mannheim-Stuttgart, Karlsruhe-Offenburg), which are not interconnected. This is the main feature of this national HRS network different from another national networks. The opening of the new section between Erfurt and Nurnberg at the end of 2017 was due to increase the total length of the national network to $1447 \mathrm{~km}$.
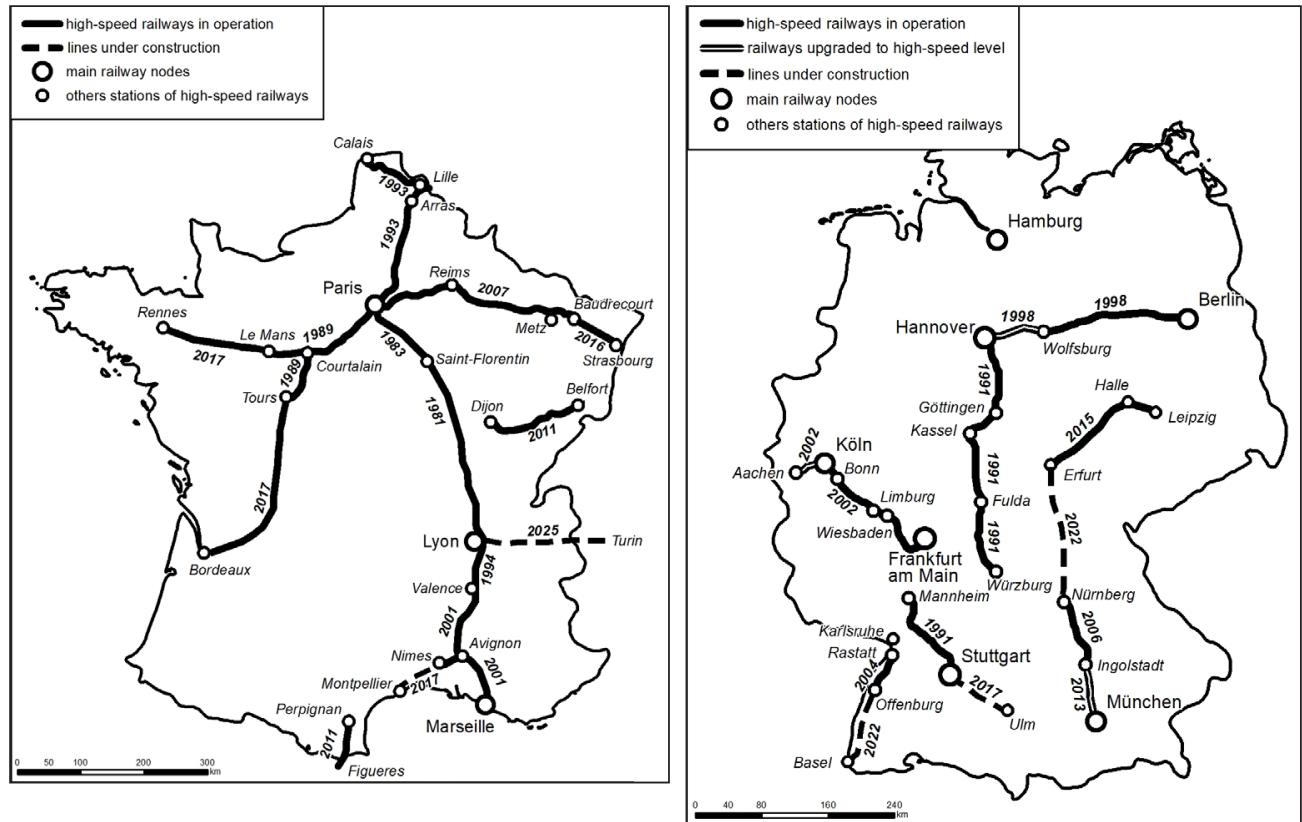

Figure 5. The high-speed railway network in France (left) and Germany (right) in 2017

The first HSR line in Italy was opened in 1977 (Fig. 6), and it was the first in Europe, albeit with the unusual direct current (DC; almost all HSR systems work from alternating current or AC). All subsequent lines have been built with alternating current. The HSR network covers $2 / 3$ of Italian territory from Torino in the north down to Salerno in the south, and has simple topological "tree" structure. The total length of the network is $1059 \mathrm{~km}$. 

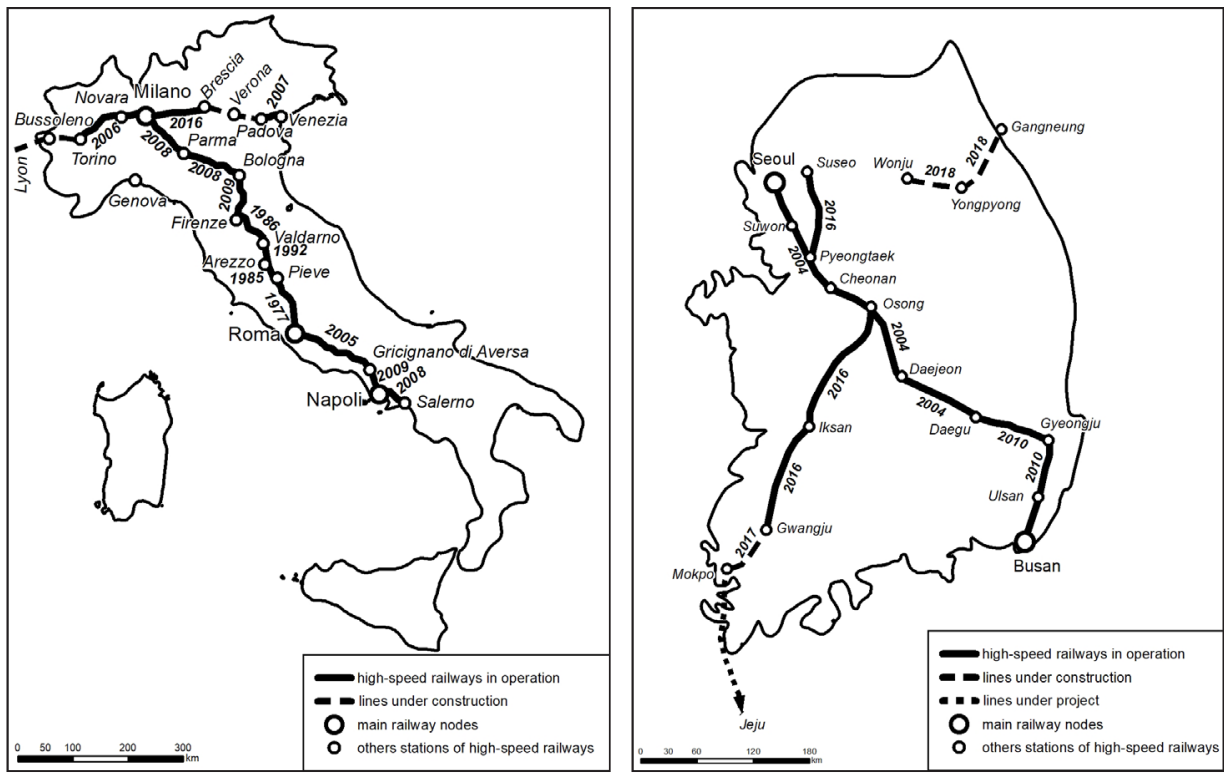

Figure 6. The high-speed railway network in Italy (left) and South Korea (right) in 2017

The first line of South Korea's HSR (Fig. 6) opened in 2004 and connected Seoul with Daegu in the south-east. It was later extended to Busan (the $2^{\text {nd }}$-biggest city) and branched to Gwangju to south-west and to Suseo in the north. The network's structure is very simple, of length $696 \mathrm{~km}$. New additions are being constructed (including an isolated fragment in the north-eastern part where the Winter Olympic Games will start in 2018) and at the planning stage.

The first, Ankara-Eskisehir line was opened in 2009 in Turkey (Fig. 7); it was augmented by branches to Konya and Pendik (near Istanbul; this section will be extended to Istanbul soon). There are also plans to build more branches. The total length now is $677 \mathrm{~km}$.
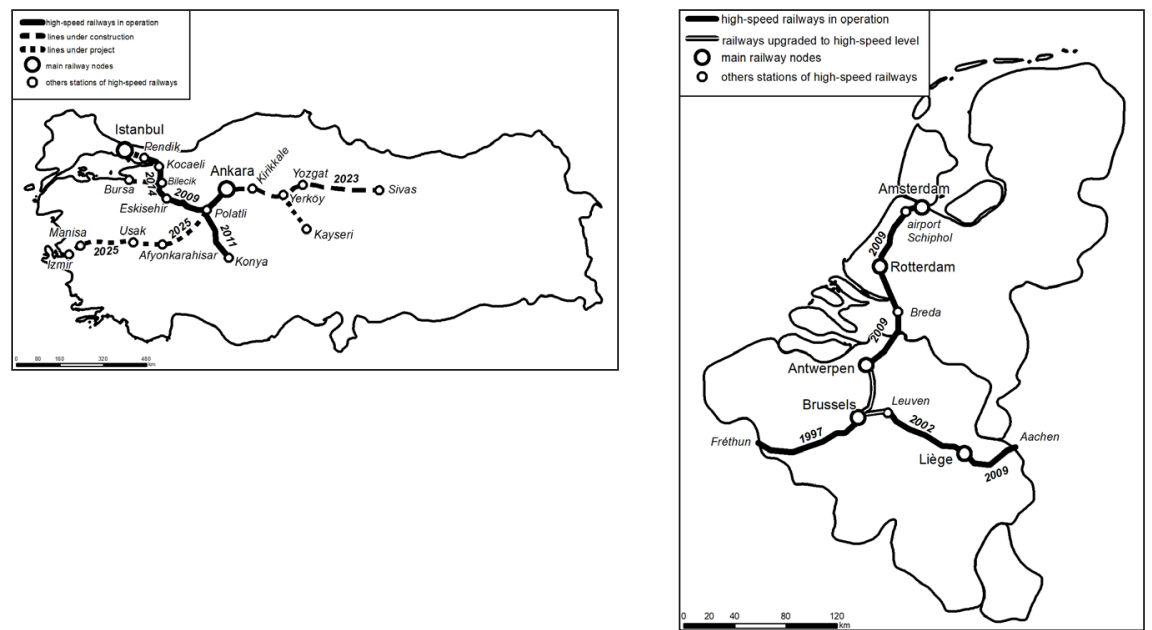

Figure 7. The high-speed railway network in Turkey (left) and Belgium and the Netherlands (right) in 2017 

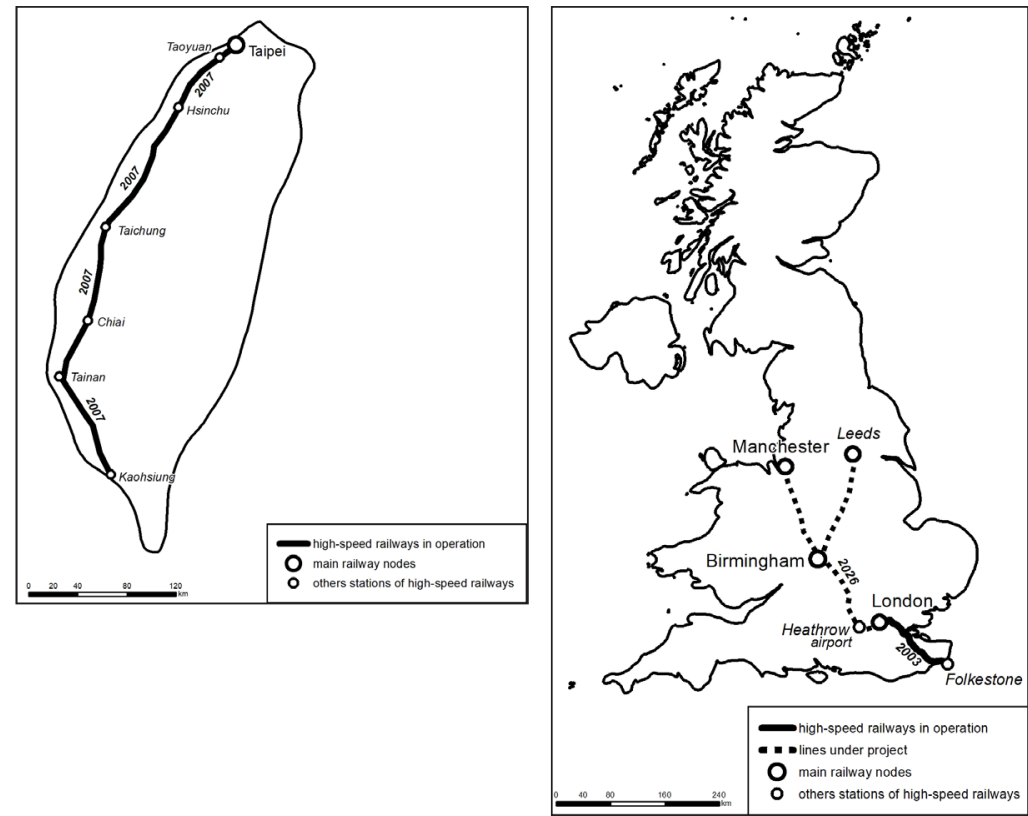

Figure 8. The high-speed railway network in Taiwan (left) and the United Kingdom (right) in 2017

Belgium and The Netherlands (Fig. 7) have a joint network, connected to the French national HSR network. The trunk line connects Paris (Lille) with Brussels, Rotterdam and Amsterdam, while a branch runs via Liege to Aachen (Germany).

In Taiwan (Fig. 8), the only HSR line is Taipei-Kaoshiung running from the north to the south (Fig. 8). It has been built in line with the Japanese Shinkansen model was and opened in 2007. Its length of $345 \mathrm{~km}$ has not changed through to the present time.

The first line in the United Kingdom from the portal of Eurotunnel near Folkestone through to the London suburbs was opened in 2003, and extended to St. Pancras railway station (London) in 2007. Its length is $113 \mathrm{~km}$ (Fig. 8), and there are plans to expand the network.

The Gautrain speed railway (not as an HSR, given its maximal speed of $160 \mathrm{~km} / \mathrm{h}$ ) was opened in 2010 in South Africa (Fig. 9); it is intercity local railway connected Johannesburg and Pretoria (Tshwane) with international airport. There are plans to build some HSR.

\section{New countries with high-speed railways}

The new HSR systems in Saudi Arabia, Morocco, Indonesia, Thailand, Malaysia and the USA were under construction in the years 2017-2018. Construction of first HSR systems will start in India, Russia, Vietnam and Mexico in the period 2018-2020. There are also projects for their construction in Kazakhstan, Israel, Canada, Argentina, Brazil and Australia (Table 3). 
Table 3. HSR systems under construction and planned

\begin{tabular}{|l|l|c|c|c|}
\hline \multicolumn{1}{|c|}{ Country } & \multicolumn{1}{|c|}{ HSR (origin and final place) } & \multicolumn{1}{|c|}{$\begin{array}{c}\text { Preliminary } \\
\text { opening dates }\end{array}$} & $\begin{array}{c}\text { Length } \\
{[\mathbf{k m}]}\end{array}$ & $\begin{array}{c}\text { Maximum } \\
\text { speed, } \\
{[\mathbf{k m} / \mathbf{h}]}\end{array}$ \\
\hline Morocco & Tangier - Kenitra & 2018 & 200 & 320 \\
\hline Saudi Arabia & Mecca - Jeddah - Rabigh - Medinah & 2018 & 453 & 300 \\
\hline Indonesia & Jakarta - Bandung & 2019 & 150 & 300 \\
\hline Thailand & Bangkok - Nakhon Ratchasima & 2019 & 256 & 250 \\
\hline USA & Madera - Fresno - Corcoran (California) & 2017 & 87 & 350 \\
\hline Malaysia & Kuala-Lumpur - Singapore & 2026 & 375 & 300 \\
\hline India & Mumbai - Thana - Surat - Vadodara - Ahmadabad & 2025 & 534 & 320 \\
\hline Russia & Moscow - Nizhniy Novgorod - Cheboksary - Kazan & 2022 & 772 & 360 \\
\hline Vietnam & Hanoi - Vinh - Hue - Da Nang - Ho Chi Minh (Saigon) & 2035 & 1570 & 300 \\
\hline Australia & Sydney - Canberra & 2035 & 283 & 350 \\
\hline Mexico & Mexico - Queretaro & $\ldots$ & 210 & 350 \\
\hline Kazakhstan & Astana - Qaraghandy - Balkhash - Taldykorgan - Almaty & $\ldots$ & 1011 & 250 \\
\hline Israel & Ashdod - Elat & $\ldots$ & 260 & 350 \\
\hline Canada & Quebec - Montreal - Ottawa - Toronto - Kitchener - & $\ldots$ & $\ldots$ & 350 \\
\hline Canada & London - Windsor & $\ldots$ & 260 & $\ldots$ \\
\hline Brazil & Edmonton - Calgary & $\ldots$ & 518 & 360 \\
\hline Argentina & Buenos-Aires - Rosario - Cordoba & $\ldots$ & 710 & 320 \\
\hline
\end{tabular}

... - no data available

Source: author's own compilation

\section{New systems of high-speed railways under construction}

The first line in Morocco, running from Tangier to Kenitra, was designed in line with a French model to be opened in 2018, and then extended to Casablanca (Fig. 9). There are plans to expand the network.

The first line in Saudi Arabia between Medina and King Abdul Aziz Airport near Jeddah will be opened in 2018 (Fig. 10). It will soon thereafter be extended to Mecca. This line has been built by a Spanish company.

Construction of the first line in Indonesia, to a Chinese model, started in 2016 and will be opened in 2019 (Fig. 11). It will connect Jakarta and Bandung. The Japanese company intends to build the line on to Surabaya.

The building of the first line in Thailand from Bangkok to the north-east started in 2016 and will be finished in 2019 (Fig. 10). There are plans to expand the network in the future.

The construction of the first HSR line in the USA (in California) started in 2015 and will finish in 2029 (Fig. 12). There are many plans to build other lines. All these HSR networks will be isolated due to the polycentric spatial structure of this large country.

In Malaysia, the construction of the first line Kuala-Lumpur-Singapore line in Malaysia started in 2017 and will be finished in 2026 (Fig. 11). 

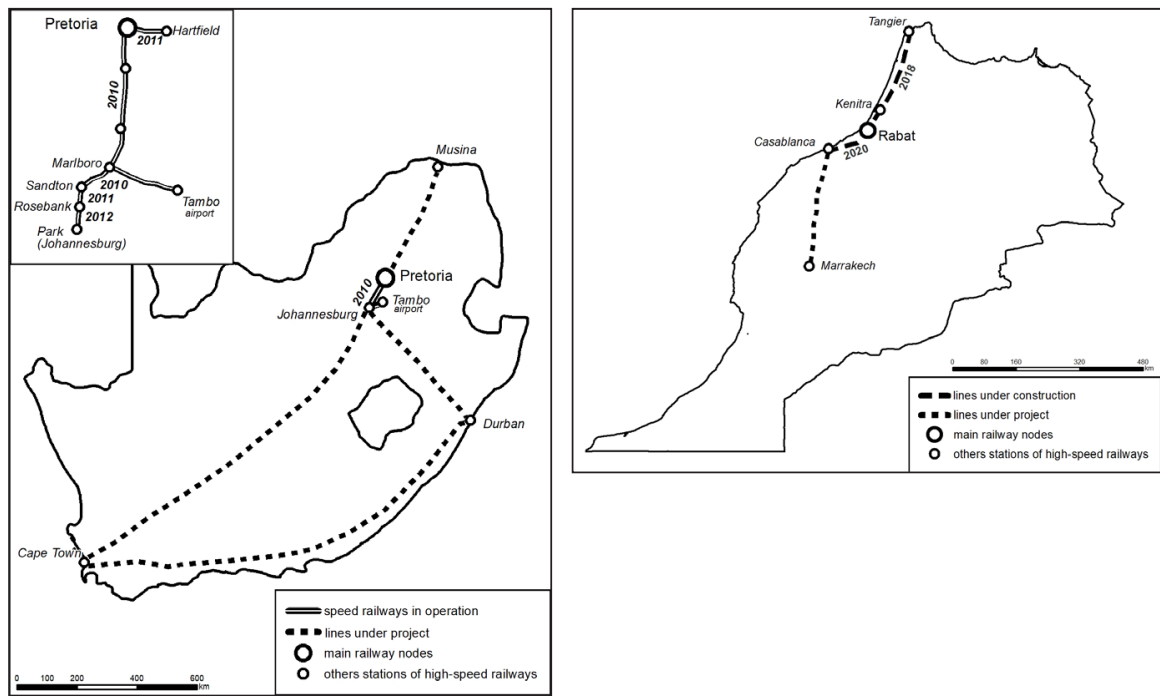

Figure 9. The high-speed railway network in South Africa (left) and the one under construction and planned in Morocco (right) in 2017
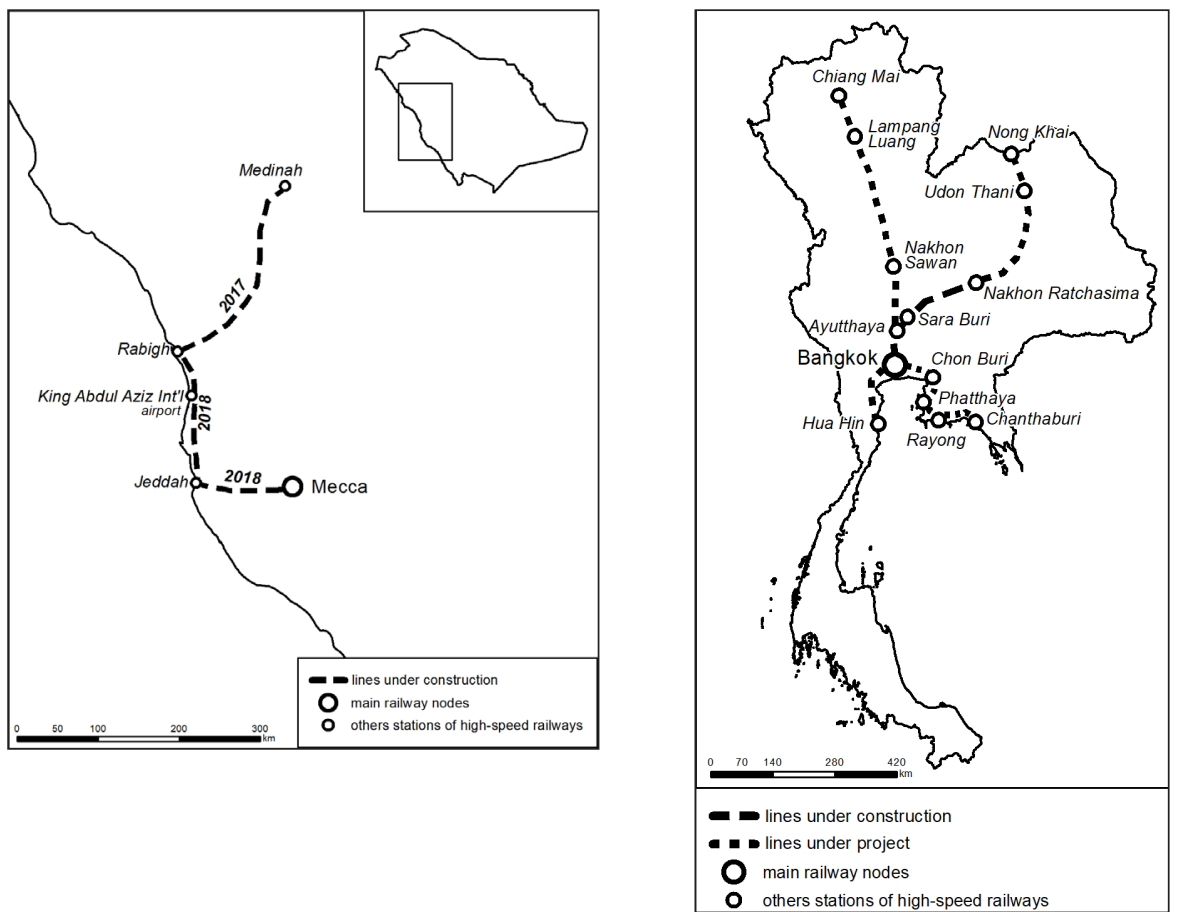

Figure 10. High-speed railways under construction and planned in Saudi Arabia (left) and Thailand (right) in 2017 

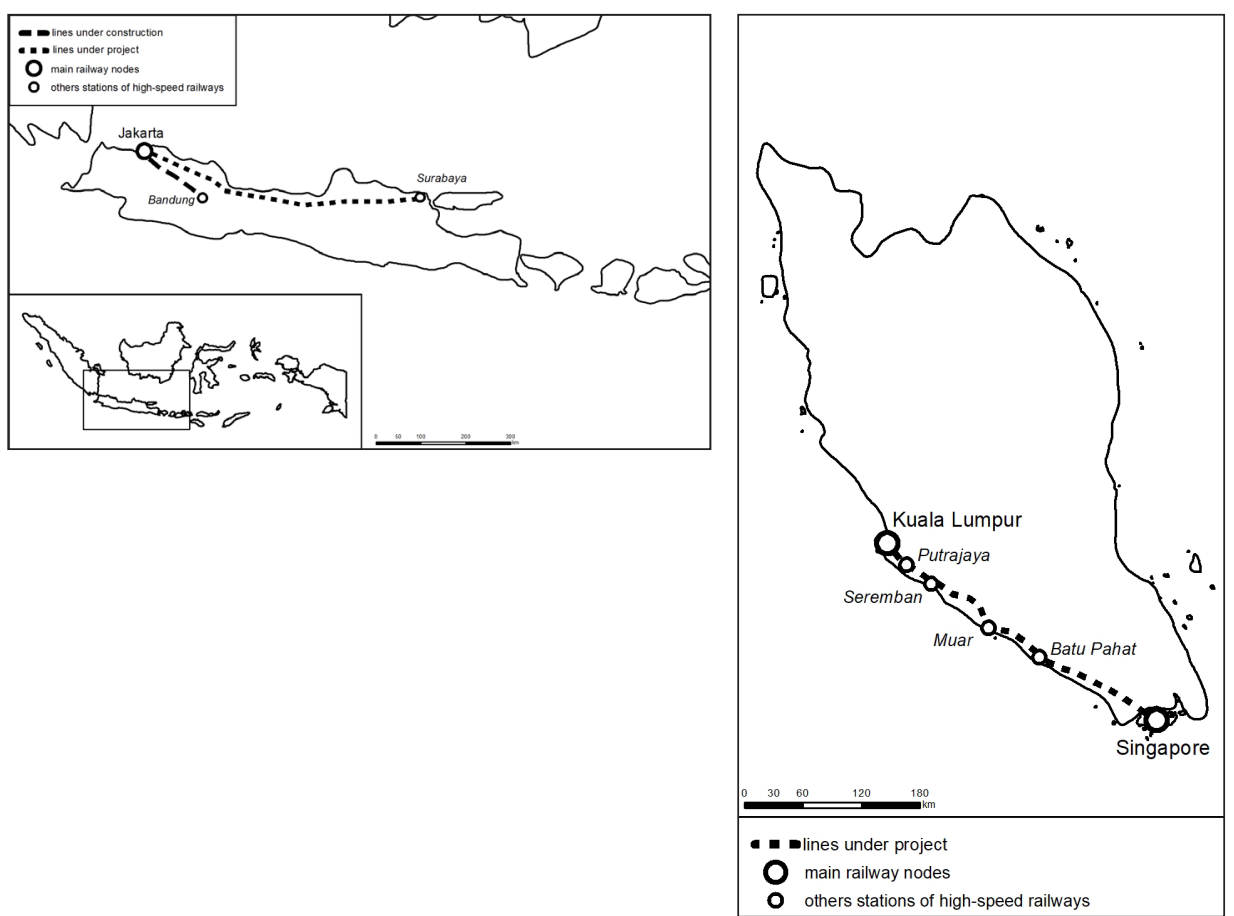

Figure 11. High-speed railways under construction and planned in Indonesia (left) and Malaysia (right) in 2017

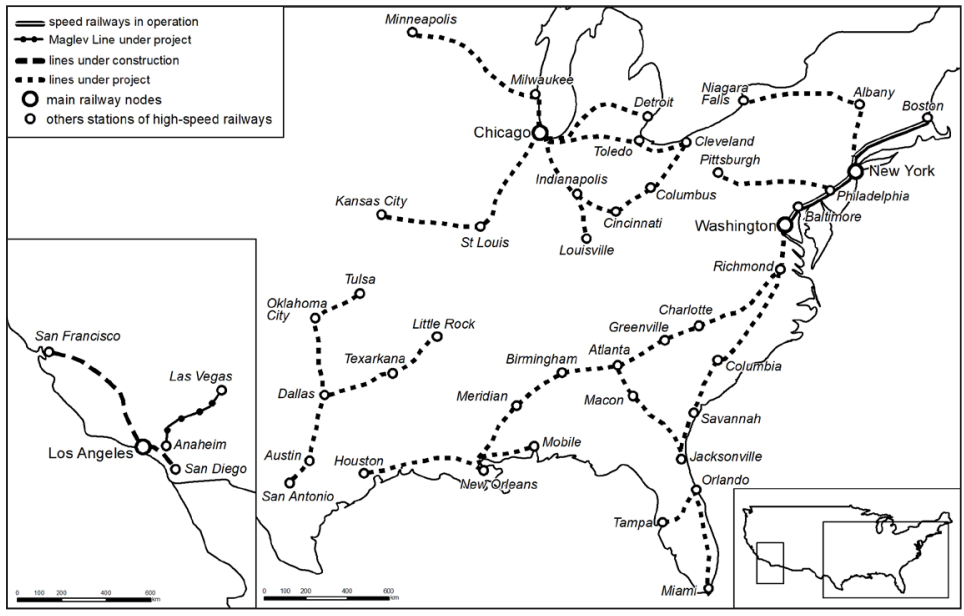

Figure 12. Speed railway in operation in 2017, high-speed railways under construction and planned in the USA

\section{Planned high-speed railway networks}

Some countries are developing plans for the construction of their first HSR systems. We present here only the maps of these plans without any review or analysis. 


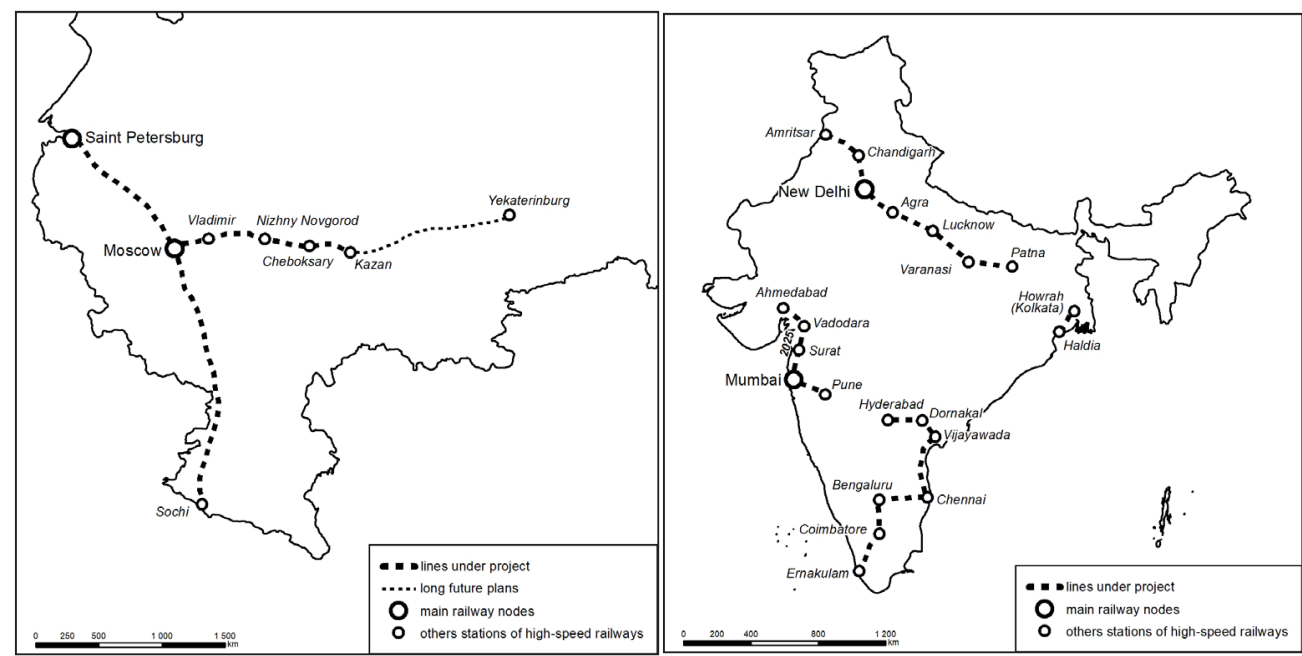

Figure 13. Planned high-speed railways in Russia (left) and India (right)

Russia plans to open its first line by 2022 with Chinese help, but construction has not yet started (Fig. 13).The construction of the first line in India (to run from Mumbai to Ahmedabad) will start in 2018 and should be finished by 2025 (Fig. 13).
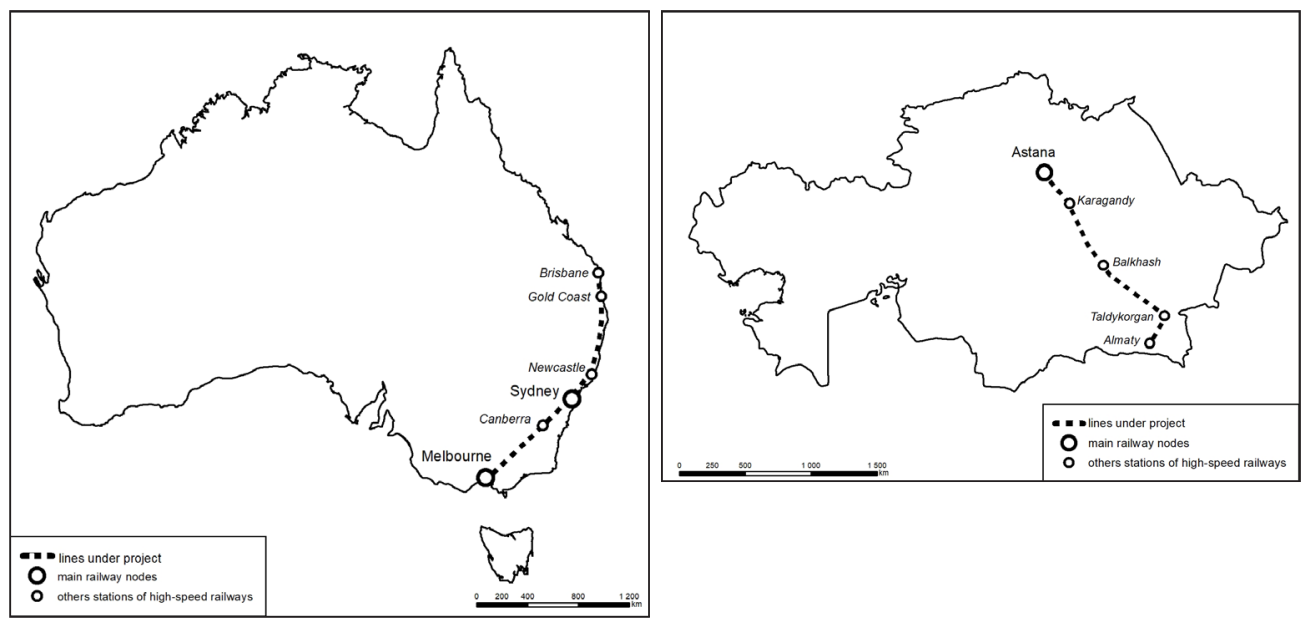

Figure 14. Planned high-speed railways in Australia (left) and Kazakhstan (right)

There is a plan that the first (Sydney-Brisbane) line in Australia will be opened in 2035 (Fig. 14).

The first longitudinal line running north-south through Vietnam will be opened by 2035 (Fig. 15). 

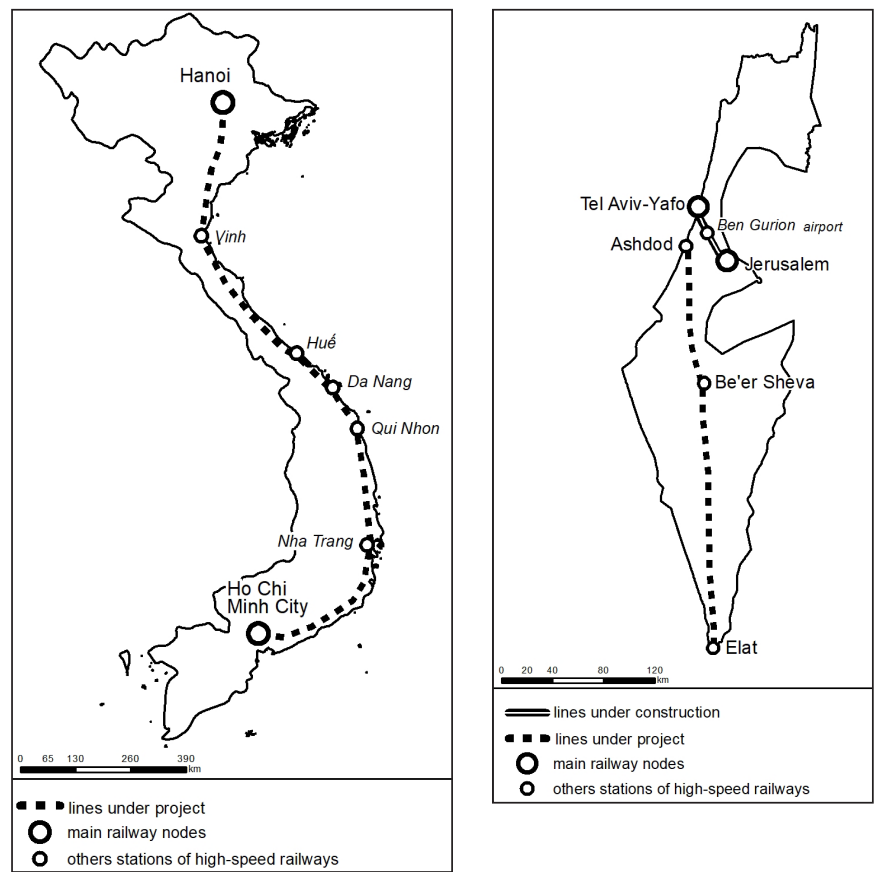

Figure 15. Planned high-speed railways in Vietnam (left) and Israel (right)

The first fast railway between Jerusalem and Tel Aviv in Israel will be opened in May 2018 (Fig. 15), but there is a plan to build an HSR from Be'er Sheva to Elat (in the far south).

There was a plan to connect the two capitals of Kazakhstan (Astana and Almaty) by HSR, but this was abandoned (Fig. 14).

There are only plans to build some HSR lines in Canada, mostly in the eastern part of the country (Fig. 16).
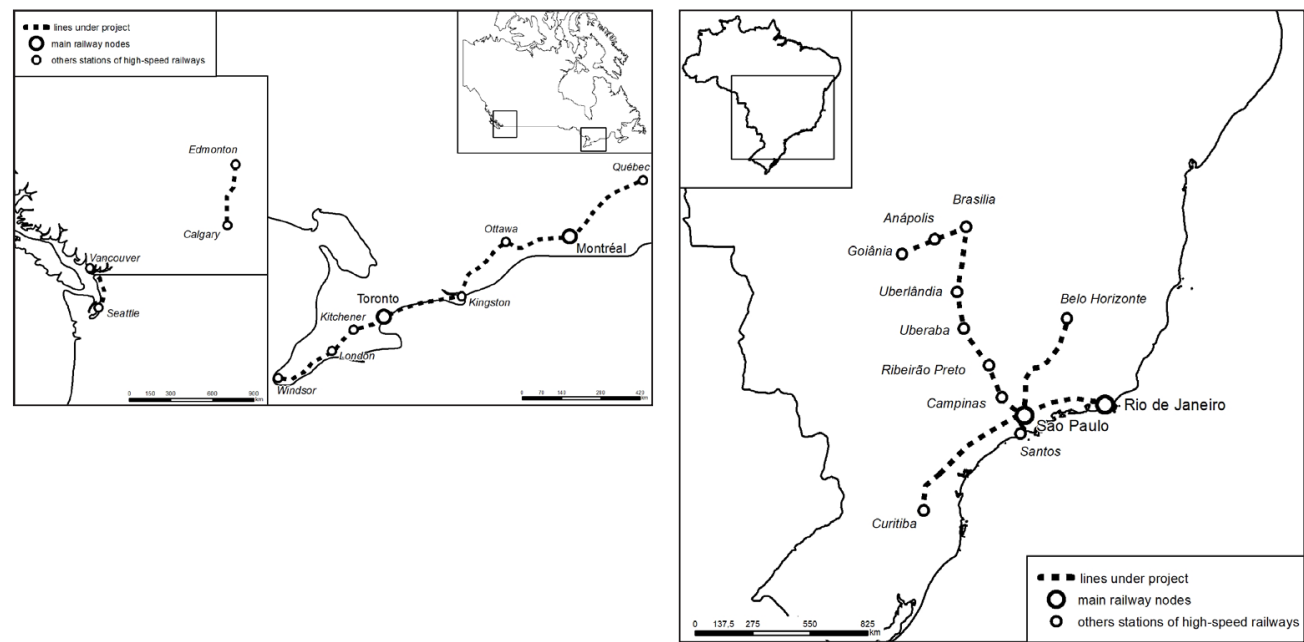

Figure 16. Planned high-speed railways in Canada (left) and Brazil (right) 

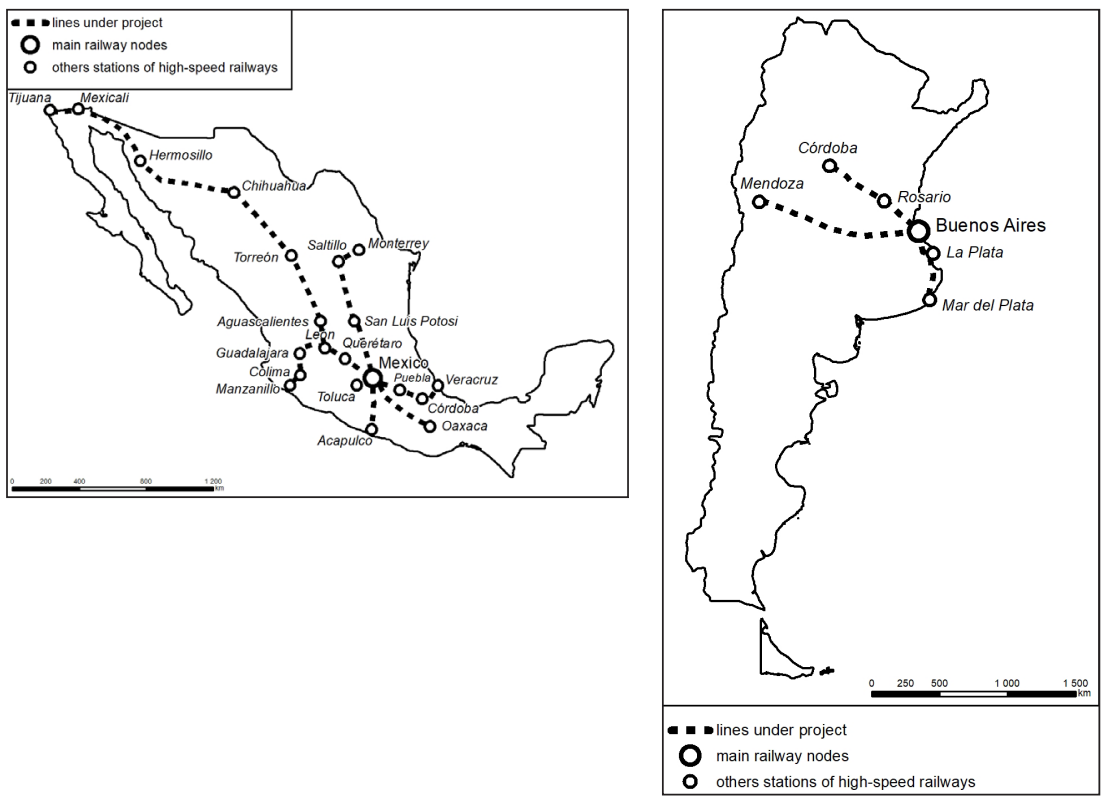

Figure 17. Planned high-speed railways in Mexico (left) and Argentina (right)

Mexico also has certain plans (Fig. 17), though it has not started with HSR construction.

Brazil began with the construction of its first HSR (running from Rio de Janeiro to Sao Paulo) in 2008, but the world financial crisis intervened. The construction of this line is nevertheless in the offing now, and there are some further plans to expand the HSR network (Fig. 16).

Two HSR lines were the subject of a project emerging in Argentina in the years 2008-12, but work on this has not commenced yet (Fig. 17).

\section{Change in the topological structure of national HSR networks}

To evaluate future change in the spatial structure of national HSR networks, we calculated certain topological measures for the networks as of 2016, as well as in relation to maximal extension (were all the projects and plans presented in Fig. 2-16 to be implemented). We have used the index 6 (see explanations below Table 4), as well as making reference to $P$, i.e. the number of isolated fragments in the network.

The HSR networks of Germany and France will have isolated fragments in the future. The same polycentric structure will also be assumed by the HSR networks in the USA ( 5 isolated subsystems), India (4) and Canada (4). Small isolated fragments will exist in China, and one in South Korea.

The topological structure of almost all national HSR networks (if all lines under construction or planning go on to be built) will not change significantly, and will thus have the same dendritic structure as now. The HSR of the USA will develop 3 circuits, Japan - one, South Africa - one. But most of the networks will become more complicated due to the construction of new branches. 8 -values will be below 0 (meaning no circuits in the structure). But 6 -values for China will increase from 1.19 to 1.26, for Japan - from 0.87 to 1.07, and for Spain - from 0.92 to 1.00, etc. 
Table 4. The level of topological complexity of national HSR networks*

\begin{tabular}{|c|c|c|c|c|c|c|c|c|}
\hline \multirow[b]{2}{*}{ Country } & \multicolumn{2}{|c|}{$\begin{array}{l}\text { Type of topological } \\
\text { structure** }\end{array}$} & \multicolumn{2}{|c|}{$\begin{array}{c}\text { Number } \\
\text { of isolated } \\
\text { components } \\
(P)^{* * *}\end{array}$} & \multirow[b]{2}{*}{$\begin{array}{l}\text { Edge number } \\
\text { (e) in } 2016 \\
\text { (following } \\
\text { implementation } \\
\text { of all projects } \\
\text { and plans) }\end{array}$} & \multirow[b]{2}{*}{$\begin{array}{c}\text { Vertex } \\
\text { number }(v) \\
\text { in } 2016 \text { (following } \\
\text { implementation } \\
\text { of all projects } \\
\text { and plans) } \\
\text { following } \\
\text { implementation } \\
\text { of all projects } \\
\text { and plans }\end{array}$} & \multicolumn{2}{|c|}{$6 * * * *$} \\
\hline & $\stackrel{\text { O্் }}{\circ}$ & 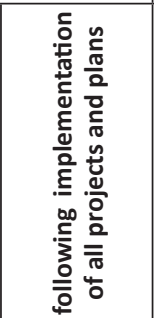 & 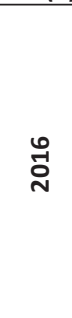 & 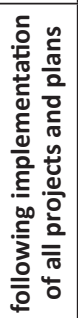 & & & O্் & 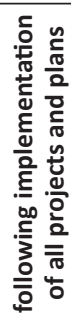 \\
\hline \multicolumn{9}{|c|}{ HSR systems in operation } \\
\hline China & \begin{tabular}{|l|} 
Circuital \\
(21 circuits)
\end{tabular} & \begin{tabular}{|l} 
Circuital \\
(41 circuits)
\end{tabular} & 3 & 3 & $113(154)$ & $95(122)$ & 1.19 & 1.26 \\
\hline Japan & Dendritic & \begin{tabular}{|l|} 
Circuital \\
(1 circuit) \\
\end{tabular} & 1 & 1 & $13(15)$ & $15(14)$ & 0.87 & 1.07 \\
\hline Spain & Dendritic & Dendritic & 2 & 1 & $23(28)$ & $25(28)$ & 0.92 & 1.00 \\
\hline Italy & Dendritic & Dendritic & 2 & 1 & $5(7)$ & $6(7)$ & 0.83 & 1.00 \\
\hline Turkey & Dendritic & Dendritic & 1 & 1 & $5(10)$ & $6(11)$ & 0.83 & 0.91 \\
\hline Belgium & Dendritic & Dendritic & 1 & 1 & $5(5)$ & $6(6)$ & 0.83 & 0.83 \\
\hline France & Dendritic & Dendritic & 3 & 3 & $14(17)$ & $17(21)$ & 0.82 & 0.81 \\
\hline South Korea & Dendritic & Dendritic & 1 & 2 & $6(8)$ & $7(10)$ & 0.86 & 0.80 \\
\hline United Kingdom & Dendritic & Dendritic & 1 & 1 & $1(4)$ & $2(5)$ & 0.50 & 0.80 \\
\hline Germany & Dendritic & Dendritic & 6 & 5 & $12(15)$ & $18(20)$ & 0.67 & 0.75 \\
\hline Taiwan & Dendritic & Dendritic & 1 & 1 & $1(1)$ & $2(2)$ & 0.50 & 0.50 \\
\hline Netherlands & Dendritic & Dendritic & 1 & 1 & $1(1)$ & $2(2)$ & 0.50 & 0.50 \\
\hline \multicolumn{9}{|c|}{ HSR systems under construction or forming the subject of projects } \\
\hline South Africa & 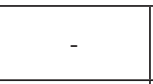 & \begin{tabular}{|l|} 
Circuital \\
(1 circuits) \\
\end{tabular} & - & 1 & (5) & (5) & - & 1.00 \\
\hline USA & - & $\begin{array}{l}\text { Circuital } \\
\text { ( } 2 \text { circuits) }\end{array}$ & - & 5 & (25) & (28) & - & 0.89 \\
\hline Thailand & - & Dendritic & - & 1 & (5) & (6) & - & 0.83 \\
\hline Russia & - & Dendritic & - & 1 & (3) & (4) & - & 0.75 \\
\hline Morocco & - & Dendritic & - & 1 & (3) & (4) & - & 0.75 \\
\hline Saudi Arabia & - & Dendritic & - & 1 & (3) & (4) & - & 0.75 \\
\hline India & - & Dendritic & - & 4 & (8) & (12) & - & 0.67 \\
\hline Indonesia & - & Dendritic & - & 1 & (2) & (3) & - & 0.67 \\
\hline Australia & - & Dendritic & - & 1 & (2) & (3) & - & 0.67 \\
\hline Canada & - & Dendritic & - & 4 & (3) & (6) & - & 0.50 \\
\hline Israel & - & Dendritic & - & 2 & (2) & (4) & - & 0.50 \\
\hline Malaysia & - & Dendritic & - & 1 & (1) & (2) & - & 0.50 \\
\hline Vietnam & - & Dendritic & - & 1 & (1) & (2) & - & 0.50 \\
\hline Kazakhstan & - & Dendritic & - & 1 & (1) & (2) & - & 0.50 \\
\hline
\end{tabular}

* The countries are listed by the level of topological complexity of HSR networks.

** Types of topological structure: "dendritic" - no closed loops in the network; "circuital" - there are closed loops (circuits) in the network, as well as dendritic forms.

*** Number of isolated components $(P)$ - the number of isolated fragments in the network.

$* * * * B-$ the connectivity index of K. Kansky (1963) shows how many lines (on average) come from each node (vertex), i.e. $b=e / v$, where $e$ is the number of edges (linear sections between transport nodes) and $v$ the number of vertices (transport nodes).

Source: author's own compilation. 


\section{Conclusions}

National high-speed rail networks (other than that of China) are of very simple dendritic topological structure. In some networks, this structure will be more complicated in the future due to the formation of circuits and many more branches, with numbers of isolated elements thus reduced. The connectivity level of these networks in polycentric or overland disconnected countries is much lower.

The main regularities to the spatial diffusion process in HSR networks are the same as for traditional land-transport networks (typical railways and roads), with: 1) sprawling of high-speed rail networks from dendritic to circuital forms; 2) spatial complication of topological structure; 3 ) dominance by the simplest networks, with complicated ones (e.g. in China) remaining a rarity.

The framework of main cities covered by high-speed railways is fast changing its functional and spatial structure due to major savings of travel time. In consequence, the largest agglomerations and megalopolises are shrinking in the time dimension (but not physically), transforming into new forms of agglomeration concentration. New high-speed corridors between the largest cities have appeared, including both high-speed railways and motorways. Spatial competitiveness between high-speed trains and regional airlines has led to the full displacement of aviation over distances up to $800 \mathrm{~km}$, with a reduction in travel costs between cities, and an increase in freedom of choice as regards routes and modes of travel. Such an improvement of spatial choice can lead to radical spatial transformations of settlement and regional and local economic systems.

High-speed railways modify not only inter-urban, but also intra-urban space: new transit-logistic hubs and retail-office complexes are forming around the new high-speed rail terminals, and this attracts other transport modes, as well as types of business new and old. New high-speed rail terminals are sometimes constructed in free sites on the outskirts of large cities, with new transport edge-cities with new functions appearing around them. These rail hubs are combined with airports in some cases (for examples, Hongqiao airport and the high-speed railway station on the western outskirts of Shanghai, Frankfurt-am-Main airport with the station for the high-speed Köln \& Frankfurt railway). Such intermodal hubs accrete as attendant services transform into brand new forms of high-tech settlement, in which creative and tertiary functions prevail.

\section{References}

142 km first phase of California's high-speed project. 2015. International Railway Journal, vol. 55, no. 8, p. 15.

770 km Moscow - Kazan high-speed line. 2015. International Railway Journal, vol. 55, no. 4, pp. 9, 11. China carries out Indian high-speed study. 2015. International Railway Journal, vol. 55, no. 5, p. 6.

Construction begins on Chuo Maglev. 2015. International Railway Journal, vol. 55, no. 2, p. 8.

France and Italy sign Lyon - Turin accord. 2015. International Railway Journal, vol. 55, no. 10, p. 10.

France and Morocco sign TGV maintenance deal. 2015. International Railway Journal, vol. 55 no. 2, p. 11. High-speed rail services in Eastern China made a profit. 2015. International Railway Journal, vol. 55, no. 4 , p. 7.

Hokuriku Shinkansen ready for launch. 2015. International Railway Journal, vol. 55, no. 2, pp. 19-21. India awards contracts for high-speed studies. 2015. International Railway Journal, vol. 55, nr. 11, p. 6. Japanese maglev reaches $600 \mathrm{~km} / \mathrm{h}$. 2015. International Railway Journal, vol. 55, no. 5, p. 7. Korean president launches KTX Honam. 2015. International Railway Journal, vol. 55, no. 5, p. 6.

Kansky K. J., 1963. Structure of transportation networks: relationships between network geometry and regional characteristics. Research Paper, no 84, 155 pp.

Mexican high-speed tender launched. 2014. International Railway Journal, vol. 54, no. 9, p. 6. 
Mexico restarts high-speed tender. 2015. International Railway Journal, vol. 55, no. 2, p. 6.

Moroccan high-speed line 70\% complete. 2015. International Railway Journal, vol. 55, no. 8, p. 7.

Munchen - Berlin in nur 4 Stunden. 2015. BauPortal, vol. 127, no. 8, p. 27.

New studies into 511 km Rio de Janeiro - Sao Paulo - Campinas high-speed line. 2015. International Railway Journal, vol. 55, no. 2, p. 7.

Spain extends Atlantic Corridor to Vigo. 2015. International Railway Journal, vol. 55 no. 5, p. 9.

Spain launches Valladolid - Leon YS line. 2015. International Railway Journal, vol. 55 no. 11, p. 6.

Tarkhov S. A., 2005. Evolutionary morphology of transportation networks. Smolensk: Eucumena (in Russian).

Tarkhov S. A., 2016. Spatial regularities of the high-speed railway growth in the world. Regional Studies (Moscow Smolensk), vol. 4, pp. 90-104. (in Russian).

Thakur R., 2015. Is India ready for high-speed rail. International Railway Journal, vol. 55, no. 7, p. $22-24$. Tunneling work completed on Jerusalem A1 link. 2014. International Railway Journal, vol. 54, no. 11 , p. 8. Wang J., Jiao J., Jin F., 2014. Spatial effects of high-speed rail on interurban economic linkages in China. Dili xuebao (Acta Geographica Sinica), vol. 69, no. 12, pp. 1833-1846.

Zhong Y., Huang J., Wen Y., 2015. Impact of high-speed railway on spatial pattern of Chinese cities accessibility. Dili kexue (Science Geography Sinica), vol. 35, no. 4, pp. 387-395. 